\title{
Formation of Oxide Scales on Zirconium Diboride-Silicon Carbide Composites During Oxidation: Relation of Subscale Recession to Liquid Oxide Flow
}

\author{
Sigrun N. Karlsdottir ${ }^{\dagger, \ddagger}$ and John W. Halloran \\ Department of Materials Science and Engineering, University of Michigan, Ann Arbor, Michigan 48104
}

\begin{abstract}
The formation of oxide scales on zirconium diboride $\left(\mathrm{ZrB}_{2}\right)$ silicon carbide ( $\mathrm{SiC}$ ) composites oxidized at high temperatures $\left(>1500^{\circ} \mathrm{C}\right)$ is studied. Subscale recession found in oxidized $\mathrm{ZrB}_{2}$ composites is proposed to form due to flow of boron oxide (boria) $\left(\mathrm{B}_{2} \mathrm{O}_{3}\right)$-rich borosilicate liquid through convection cells that form upon oxidation of the composite at high temperatures. The flow of the $\mathrm{B}_{2} \mathrm{O}_{3}$-rich liquid to the surface, with the subsequent loss of $\mathrm{B}_{2} \mathrm{O}_{3}$ to evaporation, explains the formation of a glassy silica-rich layer on the surface commonly reported in the literature. Also the outward flow of the liquid creates a localized inward path for oxygen due to lower viscosity that allows faster oxidation under the convection cells which creates the subscale recession. Optical and electron micrographs of a $\mathrm{ZrB}_{2}-15 \% \mathrm{SiC}$ composite oxidized at $1550 \mathrm{C}$ are presented as evidence of flowing liquids. Micrographs of oxide scale deformations are also presented, which are proposed to be related to the formation of oxide scale features called convection cells. The subscale recession and oxide scale deformations of $\mathrm{ZrB}_{2}$ $15 \% \mathrm{SiC}$ composites oxidized for 3 and $4 \mathrm{~h}$ at $1550 \mathrm{C}$ were studied with microstructure and chemical composition analysis.
\end{abstract}

\section{Introduction}

$\mathrm{T}$ HE zirconium diboride $\left(\mathrm{ZrB}_{2}\right)$-silicon carbide $(\mathrm{SiC})$ and $\mathrm{HfB}_{2}-\mathrm{SiC}$ composites oxidize to form a complex multilayer oxide scale at temperatures between $1400^{\circ}$ and $1700^{\circ} \mathrm{C}^{1-3}$ Often the oxide scale features a silica $\left(\mathrm{SiO}_{2}\right)$-rich outer layer, which lies over a subscale of crystalline zirconia $\left(\mathrm{ZrO}_{2}\right)$, often with a columnar microstructure with $\mathrm{SiO}_{2}$ between the $\mathrm{ZrO}_{2}$ grains. Depletion of $\mathrm{SiC}$ from the virgin material under the $\mathrm{ZrO}_{2}$ scale has also been observed and reported. ${ }^{4,5}$ While frequently observed, the mechanisms that form this complex scale are not understood in detail. ${ }^{6,7}$ The interpretation of this complex oxide scale presents several puzzles. $\mathrm{ZrO}_{2}$ appears often as a columnar subscale and as a noncolumnar phase in the $\mathrm{SiO}_{2}$ layer. Depletion of $\mathrm{SiC}$ underneath the $\mathrm{ZrO}_{2}$ scale suggests formation of $\mathrm{SiO}_{2}$ liquid or $\mathrm{SiO}$ vapor under the $\mathrm{ZrO}_{2}$, but most of the $\mathrm{SiO}_{2}$ is found over the $\mathrm{ZrO}_{2}$. The $\mathrm{SiO}_{2}$ liquid can dissolve with boron oxide (boria) $\left(\mathrm{B}_{2} \mathrm{O}_{3}\right)$ liquid (formed upon oxidation of $\mathrm{ZrB}_{2}$ ) forming a borosilicate surface layer $\left(\mathrm{B}_{2} \mathrm{O}_{3}-\mathrm{SiO}_{2}\right) . \mathrm{B}_{2} \mathrm{O}_{3}$ is, however, largely absent, due to evaporation at higher temperatures. $\mathrm{B}_{2} \mathrm{O}_{3}$ has a vapor pressure of $233 \mathrm{~Pa}$ at $1500^{\circ} \mathrm{C}^{8}$ while $\mathrm{SiO}_{2}$ has a vapor pressure of $3 \times 10^{-4} \mathrm{~Pa}^{5}$ How can these complex oxide scale features be interpreted?

Recently, Karlsdottir et al. ${ }^{9}$ proposed that liquid flow of $\mathrm{B}_{2} \mathrm{O}_{3}-\mathrm{SiO}_{2}-\mathrm{ZrO}_{2}$ (BSZ) liquids plays an important role in the formation of these scales, based on distinctive microstructural

H.-J. Kleebe- contributing editor

Manuscript No. 24490. Received March 31, 2008; approved July 10, 2008.

Author to whom correspondence should be addressed. e-mail: nanna@umich.edu

${ }^{*}$ Present address: Department of Materials, Biotechnology and Energy, Innovation Center Iceland, IS-112 Reykjavik, Iceland. features observed on the external oxide surface and in cross section.

These features are called convection cells. Figure 1 shows an example of these convection cells. The image shows a backscattering electron (BSE) image of a surface of a $\mathrm{ZrB}_{2}-15 \mathrm{vol} \% \mathrm{SiC}$ specimen oxidized at $1600^{\circ} \mathrm{C}$ for $30 \mathrm{~min}$. The surface of the oxidized specimen is covered with convection cells forming a pattern. The convection cells have $\mathrm{ZrO}_{2}$ islands (white area) located in larger $\mathrm{SiO}_{2}$-rich "lagoons"(gray area) with $\mathrm{B}_{2} \mathrm{O}_{3}$-rich patterns (dark contrast) surrounding the islands. The area around the convection cells consists of $\mathrm{a} \mathrm{SiO}_{2}$-rich glass (gray region) with small micrometer-sized $\mathrm{ZrO}_{2}$ dispersoids (white dots). The $\mathrm{B}_{2} \mathrm{O}_{3}$ flower-like patterns are visible in BSE images, but in stronger contrast when imaged by cathodoluminescence (CL). The $\mathrm{ZrO}_{2}$ islands have been proposed previously ${ }^{9}$ to have formed by precipitation during the evaporation of $\mathrm{B}_{2} \mathrm{O}_{3}$ from a $\mathrm{BSZ}$ liquid that rises through an outer $\mathrm{SiO}_{2}$-rich borosilicate layer and flows laterally by viscous fingering forming the $\mathrm{B}_{2} \mathrm{O}_{3}$-rich regions around the $\mathrm{ZrO}_{2}$ islands. ${ }^{9,10}$ The driving force is proposed to be the large volume increase upon oxidation of the bulk material due to the formation of solid $\mathrm{ZrO}_{2}(\mathrm{~s})$ and BSZ liquid. ${ }^{9}$ Figure 2 is a schematic of these convection cells and their formation.

These convection cell features had not been discussed by others before, but close examination of cross-sectional micrographs in the literature suggest that the features might have been observed, but have not be interpreted. In this paper the interpretation of oxide scale features of diboride-SiC composites will be discussed. Optical and electron micrographs will be presented as evidence of flowing liquids. Oxide scale deformation related to the formation of convection cell will also be presented and discussed. Finally, subscale recession found in oxide scales formed during oxidation of boride-SiC-based material are discussed in connection to convection cell features.

\section{Experimental Procedure: Materials and Methods}

$\mathrm{ZrB}_{2}-15 \mathrm{vol} \% \mathrm{SiC}$ composite materials were fabricated at Institute of Science and Technology for Ceramics, National Research Council (CNR-ISTEC) in Faenza, Italy, using methods presented elsewhere. ${ }^{11}$ Before testing, ca. $200 \mu \mathrm{m}$ was removed from surface by diamond grinding (Omni Brade, TBW Industries, Furlong, PA). This was to remove any heat-affected zone that could have formed during wire electrical discharge machining (w-EDM) (Ann Arbor Machine Model 1S15, Ann Arbor, MI), which was used to cut the bulk material into thin sheets. The thin sheets of the $\mathrm{ZrB}_{2}-15 \mathrm{vol} \% \mathrm{SiC}$ material were then cut with a diamond saw (IsoMet ${ }^{B} 1000$ diamond precision saw, Buehler, Lake Bluff, IL) into small rectangular coupons with total surface area on average of ca. $1 \mathrm{~cm}^{2}$. They were oxidized at high temperatures in ambient air at temperatures between $1550^{\circ}$ and $1600^{\circ} \mathrm{C}$ for different times ranging from $\frac{1}{2}$ to $4 \mathrm{~h}$. The tests were performed either in a high-temperature box furnace (SentroTech Corporation, Berea, $\mathrm{OH}$ ) or in a tube-furnace (Lindberg, Watertown, WI). The heating rate used was $13^{\circ} \mathrm{C} / \mathrm{min}$ with free cooling or with $13^{\circ} \mathrm{C} / \mathrm{min}$ cooling rate. In the 

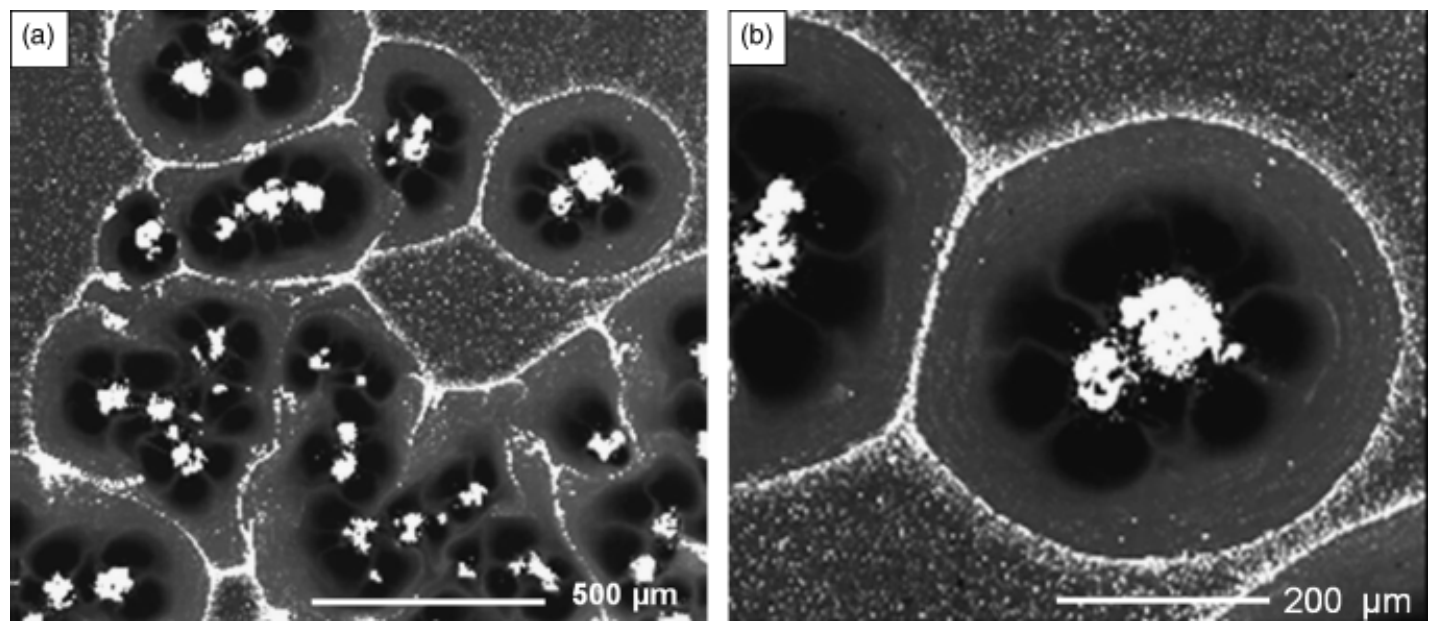

Fig. 1. Backscattered electron images of the surface of a $\mathrm{ZrB}_{2}-15$ vol\% $\mathrm{SiC}$ composite oxidized at $1600^{\circ} \mathrm{C}$ for $30 \mathrm{~min}$. (a) Surface covered with convection cells that have $\mathrm{ZrO}_{2}$ islands (white) located in larger $\mathrm{SiO}_{2}$, lagoons (gray) with $\mathrm{B}_{2} \mathrm{O}_{3}$-rich patterns (black) surrounding the islands. (b) Higher magnification of a convection cell.

furnace the specimens were supported by the same material $\left(\mathrm{ZrB}_{2}-\mathrm{SiC}\right)$ that was placed on an $\mathrm{Al}_{2} \mathrm{O}_{3}$ support in an $\mathrm{Al}_{2} \mathrm{O}_{3}$ crucible.

Chemical composition and microstructural analysis were done on the surfaces and cross sections of the oxidized specimens using bright field optical microscopy of the as-oxidized surface, scanning electron microscopy, BSE microscopy, and electron microprobe analyzer (EMPA). A Cameca SX100 was used for EMPA, using well-characterized mineral standards for quantitative analysis of boron (B), oxygen $(\mathrm{O})$, zirconium $(\mathrm{Zr})$, and silicon $(\mathrm{Si})$, and for imaging in the BSE and CL modes. The EMPA standards and technique that were used are described in more detail elsewhere. ${ }^{9}$ The cross sections of the oxidized specimens were prepared for microstructural analysis by nonaqueous polishing procedures down to $1 \mu \mathrm{m}$ finish. Specimens were coated with carbon before microstructural and elemental analysis.

\section{Interpretation of Oxide Scale}

Examination of the surface of the oxidized samples provides clear evidence of liquid flow. Figure 3(a) is an optical micrograph of the surface after oxidation for $4 \mathrm{~h}$ at $1550^{\circ} \mathrm{C}$. Optical metallograph image in reflected light shows what appears to be "islands" of $\mathrm{ZrO}_{2}$ in a film of borosilicate glass. These islands are assemblies of $\mathrm{ZrO}_{2}$ grains emerging from the once-liquid glassy surface. The darker regions of the glass are rich in $\mathrm{SiO}_{2}$, and are dark because of the relative transparency scatters little of the incident light. Very small dispersed $\mathrm{ZrO}_{2}$ particles barely visible are on the surface of the $\mathrm{SiO}_{2}$. The cloudy features are subsurface $\mathrm{B}_{2} \mathrm{O}_{3}$-rich borosilicate. These borosilicate regions are turbid because of liquid-liquid phase separation in the glass during cooling. The appearance of the turbid and clear regions of

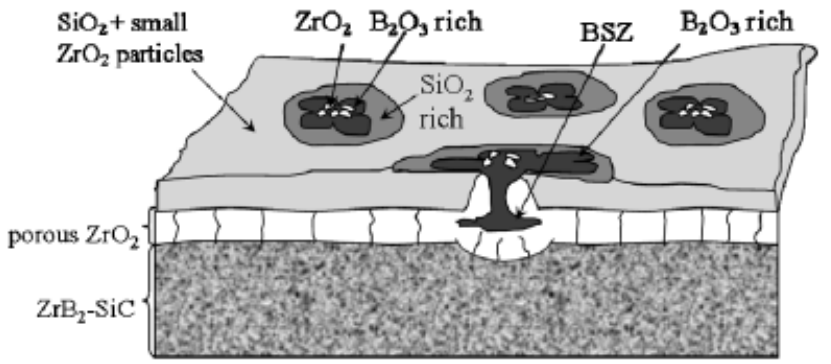

Fig. 2. Schematic of the convection cell features seen on surfaces and cross sections of $\mathrm{ZrB}_{2}-\mathrm{SiC}$ composites oxidized at temperatures between $1500^{\circ}$ and $1600^{\circ} \mathrm{C}$. The schematic shows convection cells spread on the surface with their $\mathrm{ZrO}_{2}$ islands (white) located in larger $\mathrm{SiO}_{2}$, lagoons (light gray) with $\mathrm{B}_{2} \mathrm{O}_{3}$-rich patterns (dark gray) surrounding the islands. the glass is suggestive of liquids flowing from the neighborhood of the $\mathrm{ZrO}_{2}$ island. Figure 3(b) is a BSE image of the same field of view as Fig. 3(a). In BSE imaging, the $\mathrm{ZrO}_{2}$ islands appear in bright contrast. The $\mathrm{SiO}_{2}$-rich glassy regions appear in light gray contrast, and the $\mathrm{B}_{2} \mathrm{O}_{3}$-rich regions in darker contrast. The small dispersed $\mathrm{ZrO}_{2}$ particles on the $\mathrm{SiO}_{2}$ are highly visible. The arrangement of these small $\mathrm{ZrO}_{2}$ dispersoids is hard to understand without presuming that they were arranged by flowing liquids. We present these images as evidence in support of the hypothesis of convective flow, as illustrated in the schematic of Fig. 2.

Now let us direct our attention to cross section of the oxide scales. Figures 4(a)-(c) show BSE images of a cross section of a $\mathrm{ZrB}_{2}-15 \mathrm{vol} \% \mathrm{SiC}$ specimen oxidized at $1550^{\circ} \mathrm{C}$ for $3 \mathrm{~h}$ in a tube-furnace in ambient air, with a heating rate of $13^{\circ} \mathrm{C} / \mathrm{min}$ and free cooling. The images show significant deformations of the oxide scale. The $\mathrm{SiO}_{2}$ outer scale appears in the BSE image in darker contrast, while the $\mathrm{ZrO}_{2}$ subscale is in brighter contrast. The contrast between $\mathrm{ZrO}_{2}$ and $\mathrm{ZrB}_{2}$ is slight in this image. The higher magnifications, Figs. 4(b) and (c), show that the $\mathrm{ZrO}_{2}$ scale is deformed; it appears to be lifted up, like a blister. Inside the "blister" is a glassy phase shown by EMPA maps and analysis to be rich in $\mathrm{B}_{2} \mathrm{O}_{3}, \mathrm{SiO}_{2}$, and with some $\mathrm{ZrO}_{2}$.

Figures 5(a)-(e) show a BSE image of one of the deformations shown in Fig. 4(a) and the corresponding EMPA maps of this area, showing the distribution of $\mathrm{B}, \mathrm{Si}, \mathrm{O}$, and $\mathrm{Zr}$. The distinction between the $\mathrm{ZrO}_{2}$ in the primary scale and the $\mathrm{ZrB}_{2}$ substrate can be made by comparing the zirconium image Fig. 5(c) with the boron image Fig. 5(e) and the oxygen image Fig. 5(b). Clearly the $\mathrm{ZrB}_{2}$ substrate and the $\mathrm{ZrO}_{2}$ primary scale are being separated by a liquid rich in $\mathrm{O}, \mathrm{Si}$, and $\mathrm{B}$, with significant distortion of the $\mathrm{ZrO}_{2}$ primary scale. Figure 6 shows the corresponding line analysis from these elemental maps, indicating that the glass inside the "blister" is rich in $\mathrm{B}_{2} \mathrm{O}_{3}$, and $\mathrm{SiO}_{2}$, and has some $\mathrm{ZrO}_{2}$. Based on a calculated ternary phase diagram of a $\mathrm{ZrO}_{2}-\mathrm{SiO}_{2}-\mathrm{B}_{2} \mathrm{O}_{3}$ system, an isothermal section at $1500^{\circ} \mathrm{C}$, published previously by Karlsdottir et al. ${ }^{10}$ it is presumed that this material is the glass formed by cooling of a BSZ liquid in equilibrium with $\mathrm{ZrO}_{2}(s)$ at this temperature $\left(1550^{\circ} \mathrm{C}\right)$.

The driving force for these deformations is likely the very large volume increase upon oxidation of the bulk material due to the formation of condensed oxides, solid $\mathrm{ZrO}_{2}(s)$ and BSZ liquid, where the oxide products occupy a volume 3.2 times as great as the $\mathrm{ZrB}_{2}-\mathrm{SiC}$ substrate. ${ }^{9}$ From the microstructural and chemical compositional analysis of the blisters (deformations) we propose that the BSZ liquid forms at the reaction interface, i.e. between a "primary" oxide scale (a thin outer $\mathrm{SiO}_{2}$-rich borosilicate layer and an underlying porous $\mathrm{ZrO}_{2}(s)$ ) and the unreacted bulk material. Here it is hypothesized that the blisters 

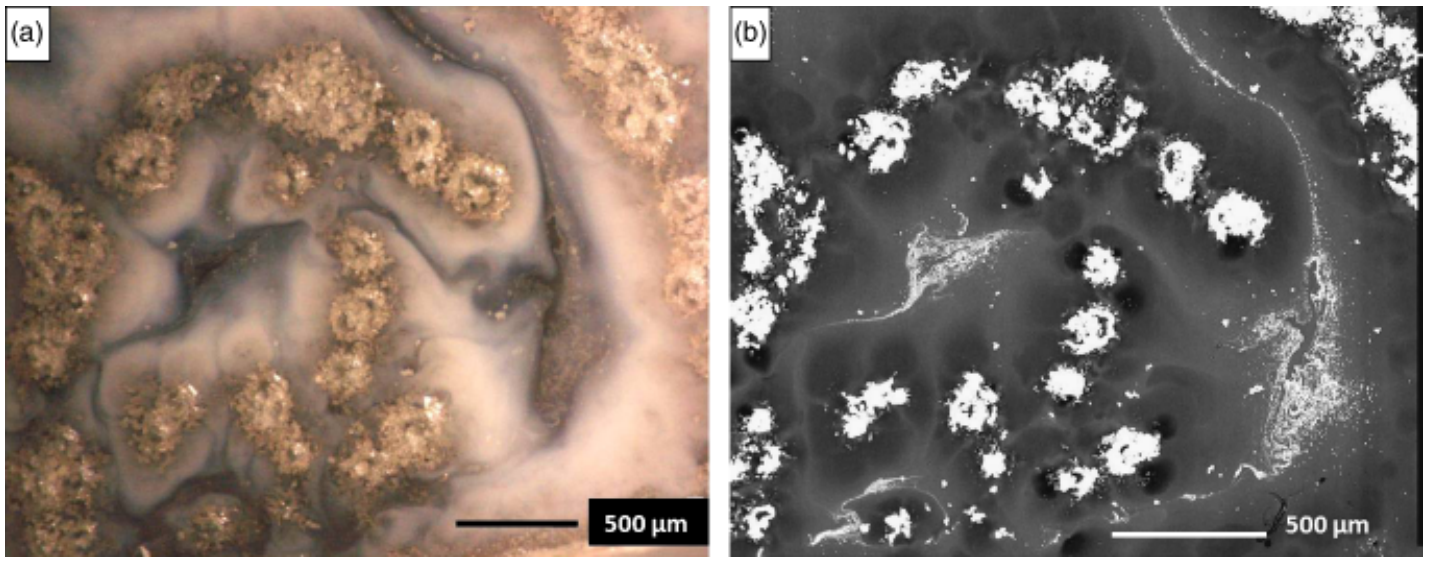

Fig. 3. Surface of an oxide scale on $\mathrm{ZrB}_{2}-15$ vol\% $\mathrm{SiC}$ composite after oxidation for $4 \mathrm{~h}$ at $1550^{\circ} \mathrm{C}$. (a) Optical image in reflected light, showing "islands" of $\mathrm{ZrO}_{2}$ in a film of borosilicate glass. The darker regions of the glass are rich in $\mathrm{SiO}_{2}$, which are dark because of transparency, with small dispersed $\mathrm{ZrO}_{2}$ particles barely visible. The cloudy regions are $\mathrm{B}_{2} \mathrm{O}_{3}$-rich borosilicate, turbid because of liquid-liquid phase separation in the glass during cooling, (b) backscattered electron image of the same region, where $\mathrm{ZrO}_{2}$ islands appear in bright contrast, $\mathrm{SiO}_{2}$-rich glassy regions in light gray contrast, and $\mathrm{B}_{2} \mathrm{O}_{3}$-rich regions in dark gray contrast. The small dispersed $\mathrm{ZrO}_{2}$ particles on the $\mathrm{SiO}_{2}$ appear in bright contrast.

form because of the large volume increase, induced by the formation of the oxides during oxidation. The large volume increase of the formed oxides induces pressure and stresses when the oxide scale grows leading to a rupture in the "primary" oxide scale. Our hypothesis is that the BSZ liquid at the reaction interface is then squeezed up to the surface where it starts flowing, forming the convection cells and their features.

Figure 4(d) shows a secondary electron image of a polished cross section of a convection cell on an oxidized $\mathrm{ZrB}_{2}-\mathrm{SiC}$ sam- ple. The sample was oxidized for $4 \mathrm{~h}$ at $1550^{\circ} \mathrm{C}$ in a tube-furnace in ambient air, with a heating rate of $13^{\circ} \mathrm{C} / \mathrm{min}$ and free cooling. The image shows the $\mathrm{SiO}_{2}$-rich external scale, in dark gray contrast, covering a $\mathrm{ZrO}_{2}$ subscale (primary $\mathrm{ZrO}_{2}$ ) in light gray contrast, over the unoxidized $\mathrm{ZrB}_{2}-\mathrm{SiC}$ substrate. The $\mathrm{ZrO}_{2}$ "island" impinging on the surface (formed by precipitation of $\mathrm{ZrO}_{2}$ ) is seen in cross section to be a vertical feature containing region of glass in the middle. The glass contains $\mathrm{B}_{2} \mathrm{O}_{3}, \mathrm{SiO}_{2}$, and some $\mathrm{ZrO}_{2}$, it is also richer in boron (B) than the glass outside of
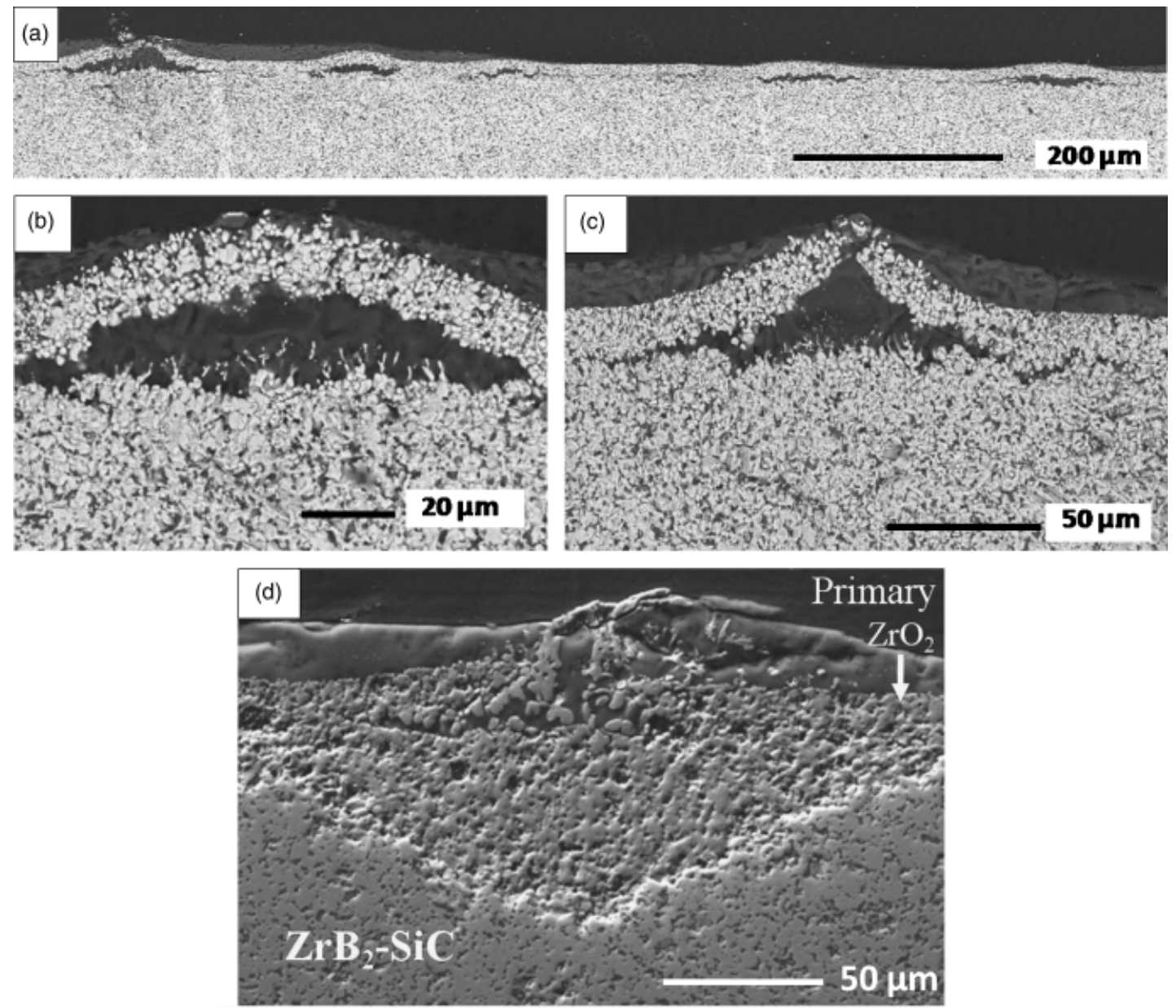

Fig. 4. (a)-(c) Backscattered electron images of cross sections of $\mathrm{ZrB}_{2}-15 \mathrm{vol} \% \mathrm{SiC}$ composite oxidized for $3 \mathrm{~h}$, showing the built up of the $\mathrm{BSZ}$ liquid between the "primary" oxide scale $\left(\mathrm{SiO}_{2}\right.$-rich top layer and an under laying $\left.\mathrm{ZrO}_{2}\right)$ and the bulk material $\left(\mathrm{ZrB}_{2}-\mathrm{SiC}\right)$. (d) Scanning electron microscopic image of a cross section of a convection cell on $\mathrm{ZrB}_{2}-\mathrm{SiC}$ oxidized at $1550^{\circ} \mathrm{C}$ for $4 \mathrm{~h}$, showing the inner structure of a convection cell. 

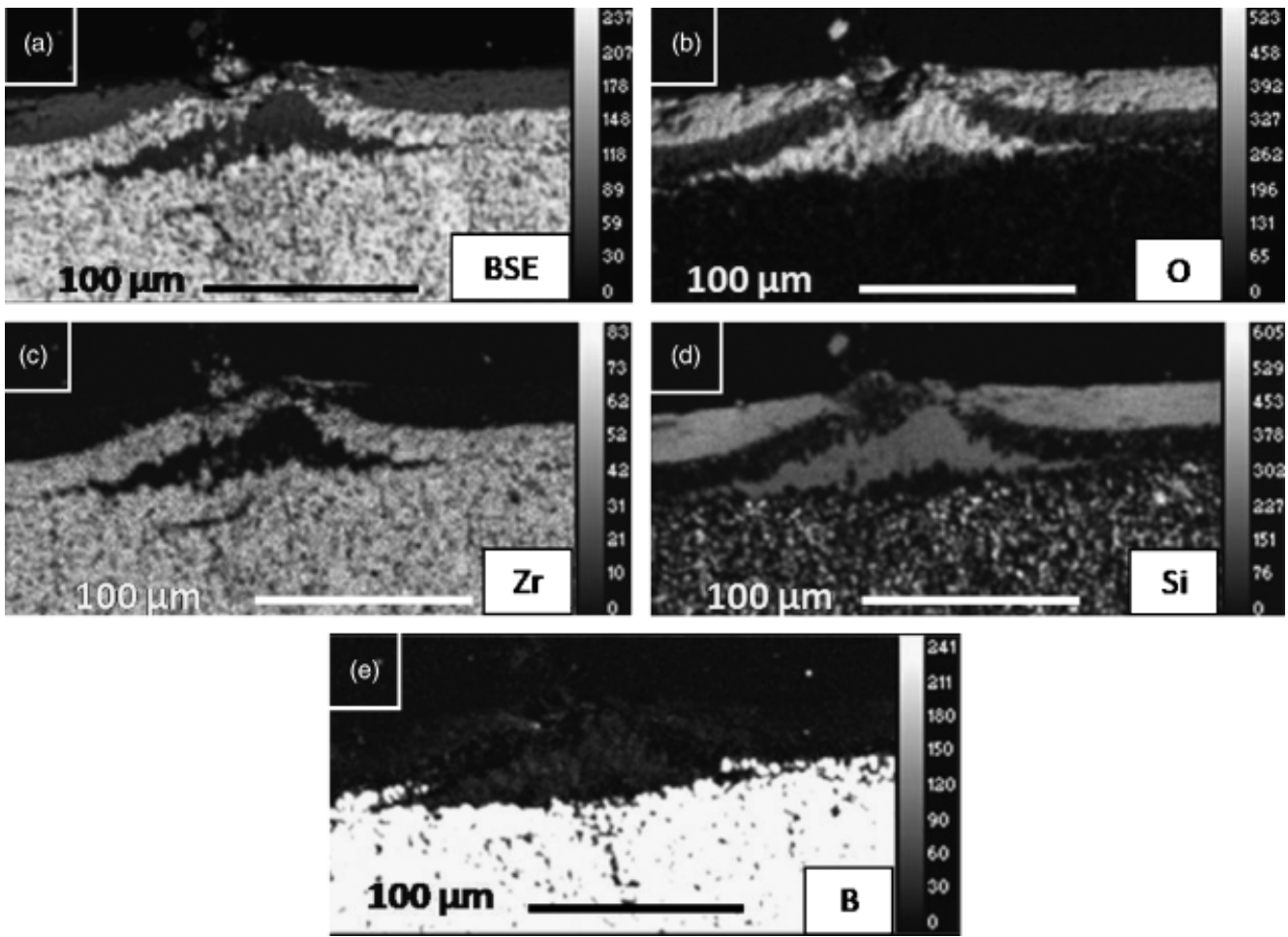

Fig. 5. (a) Backscattered electron (BSE) image of a deformation with glass inside located in the cross section of the $\mathrm{ZrB}_{2}-15 \% \mathrm{SiC}$ composite oxidized at $1550^{\circ} \mathrm{C}$ for $3 \mathrm{~h}$; (b)-(e) the same area as in (a) imaged by electron microprobe analysis in oxygen Ka X-rays (b), zirconium La X-rays (c), silicon Ka $\mathrm{X}$-rays (d), and boron Ka X-rays (e). The scale bars on the elemental maps represent the intensity of the corresponding element. The elemental maps (b)(e) indicate $\mathrm{SiO}_{2}$-rich surface layer and underlying $\mathrm{ZrO}_{2}$ layer as well as the composition of the BSZ glass inside the deformation.

(a)

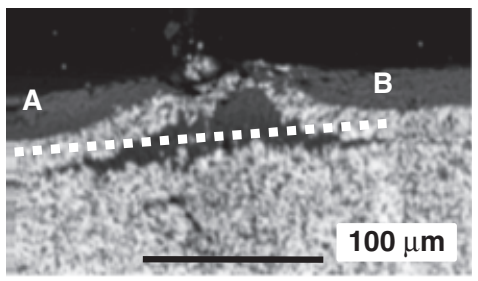

(b)
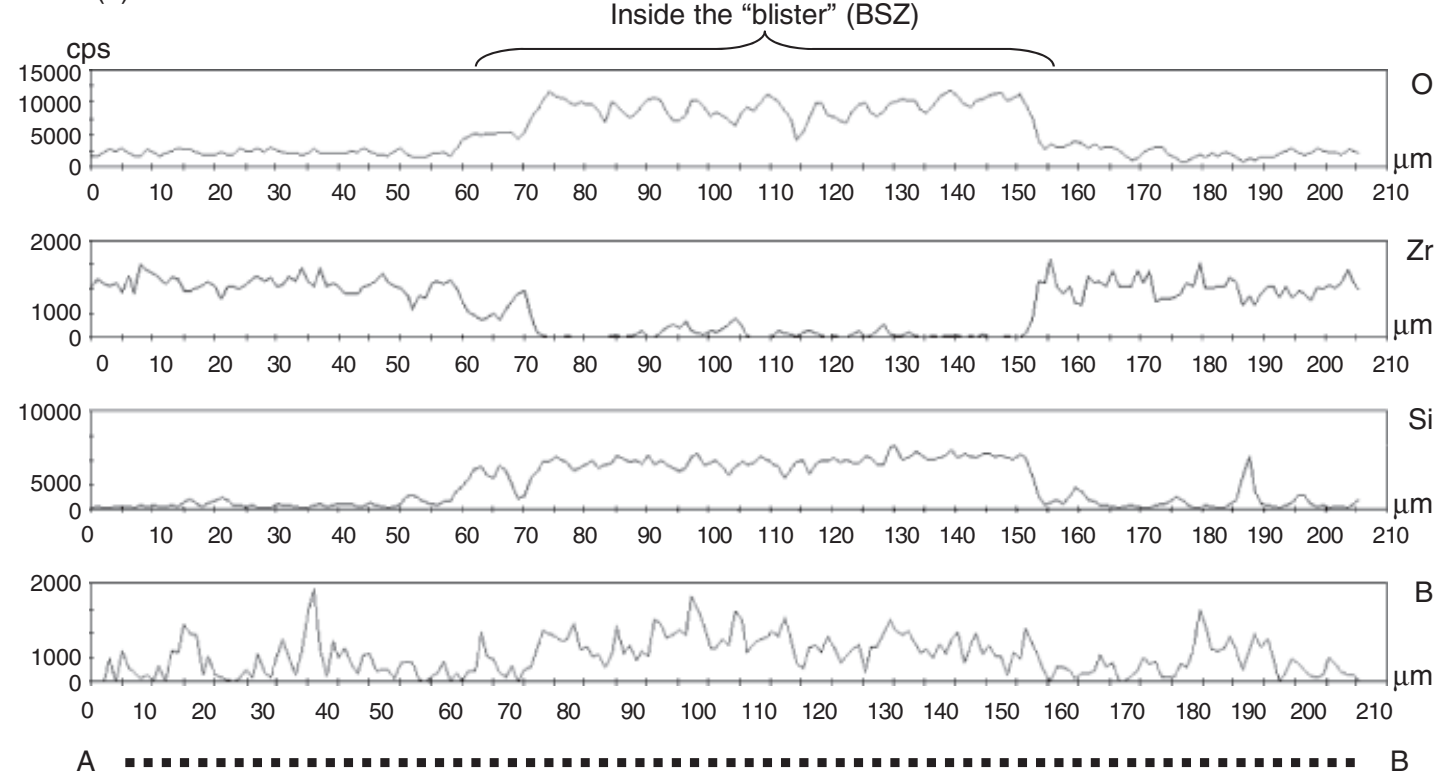

Fig. 6. (a) Backscattered electron image of a cross section of a cell on surface of a $\mathrm{ZrB}_{2}-15 \mathrm{vol} \% \mathrm{SiC}$ composite oxidized at $1550^{\circ} \mathrm{C}$ for $3 \mathrm{~h}$. The white line through the "blister" (deformation) indicates where the EPMA line analyses were done; the letter A indicates the start of the line scan and B the end (b) graphs of the recorded intensity ((Cps) counts per second) versus distance $(\mu \mathrm{m})$ of the line scan. 


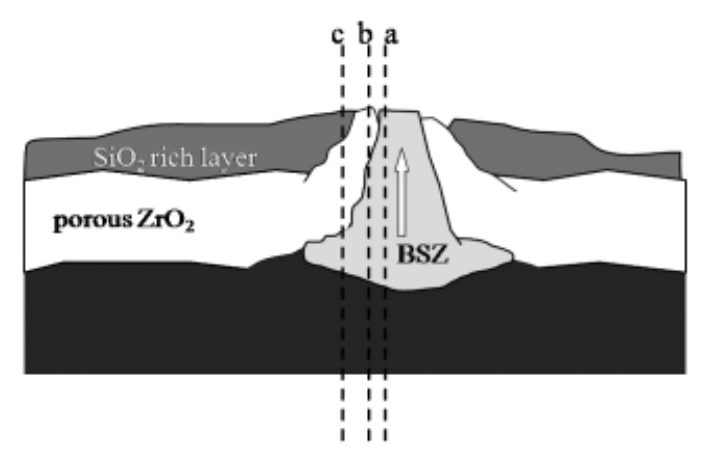

Fig. 7. Schematic showing different planes of cross sections possible through a convection cell, showing the inner structure of the cell.

the $\mathrm{ZrO}_{2}$ "island", suggesting this to be the glass of the $\mathrm{B}_{2} \mathrm{O}_{3}$ rich BSZ liquid. Note that the interface between the "primary" $\mathrm{ZrO}_{2}$ subscale and the unoxidized $\mathrm{ZrB}_{2}-\mathrm{SiC}$ substrate extends about $100 \mu \mathrm{m}$ beneath the surface under the $\mathrm{ZrO}_{2}$ "island" (the center of the convection cell) but only about $50 \mu \mathrm{m}$ away from the center of the convection cell. Apparently this increased subscale recession of the $\mathrm{ZrB}_{2}-\mathrm{SiC}$ substrate denotes faster oxidation at this location.

When interpreting the cross-sectional images of the deformations shown in Fig. 4, one needs to consider that because the location of the plane of polish is not known, it is hard to infer if the features seen differ because of their location, or if they differ because they have not developed (immature or "before eruption") or have stopped operating ("extinct"). Figure 7 is an illustration of a convection cell intersected by several planes of cross section for polish. Line "a" in Fig. 7 intersects the center of
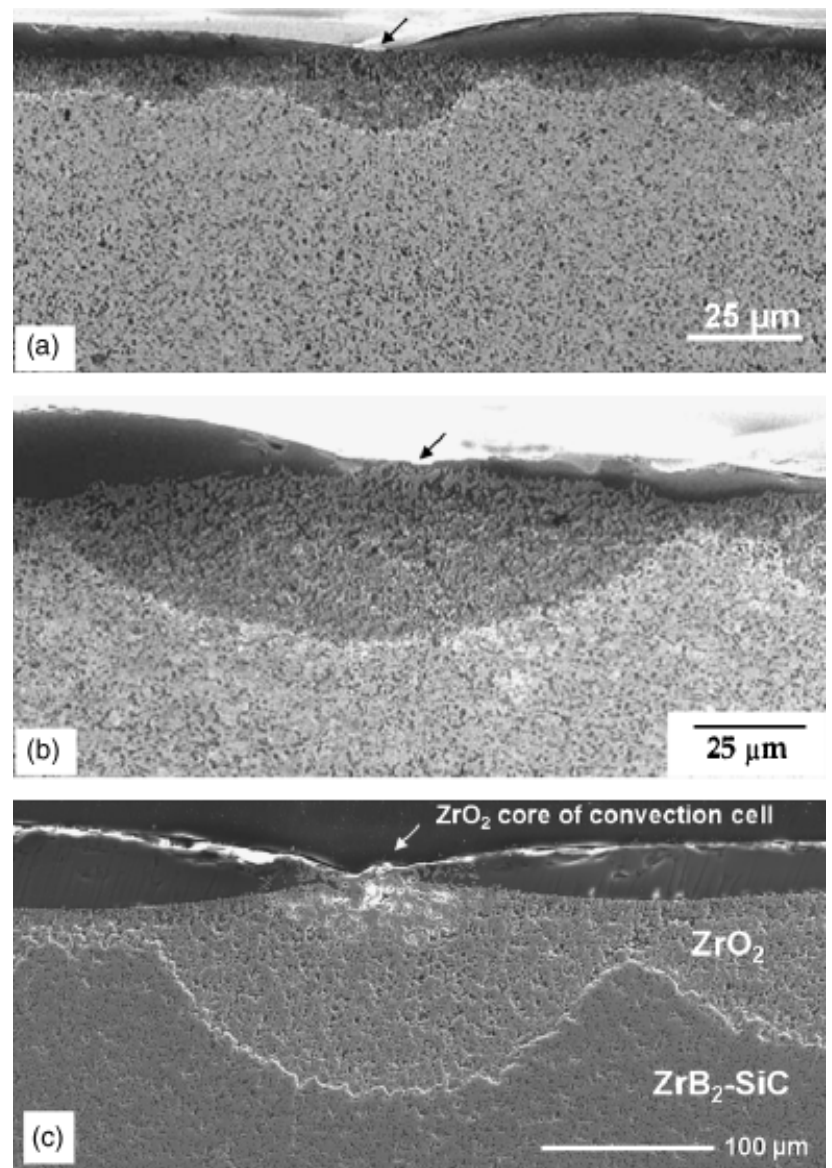

Fig. 8. Scanning electron microscopic images of the cross sections of diboride/silicon carbide composites. (a) $\mathrm{HfB}_{2}-\mathrm{SiC}-\mathrm{HfN}$ and (b) $\mathrm{ZrB}_{2}$ $\mathrm{HfB}_{2}-\mathrm{SiC}-\mathrm{HfN}$ composites oxidized at $1450^{\circ} \mathrm{C}$ for $20 \mathrm{~h}$ by Monteverde $^{12}$; (c) a $\mathrm{ZrB}_{2}-15 \% \mathrm{SiC}$ composite oxidized at $1550^{\circ} \mathrm{C}$ for $2 \mathrm{~h}$. a BSZ liquid pipe. This can create an image similar to Fig. 4(d). If the plane of polish intersects the side of a convection cell (through a $\mathrm{ZrO}_{2}$ "island" filled with liquid), i.e. line " $b$ ", it could create an image similar to Fig. 4(c), while a plane of polish more remote from the pipe (line "c") could create an image similar to Fig. 4(b).

\section{Comparison with Literature}

Microstructural features closely resembling the convection cells have been reported earlier in the literature but not interpreted as of significance. Figure 8 compares previously published images of specimens oxidized at CNR-ISTEC by Monteverde ${ }^{12}$ with a specimen oxidized at University of Michigan (UM). Cross sections of $\mathrm{HfB}_{2}-\mathrm{SiC}-\mathrm{HfN}$ and $\mathrm{ZrB}_{2}-\mathrm{HfB}_{2}-\mathrm{SiC}-\mathrm{HfN}$ composites oxidized at $1450^{\circ} \mathrm{C}$ for $20 \mathrm{~h}$ by Monteverde ${ }^{12}$ at CNR-ISTE are shown in Figs. 8(a) and (b). The images show vertical $\mathrm{ZrO}_{2}$ features on top of an enhanced oxidation zone (increased thickness of $\mathrm{ZrO}_{2}$ layer). Figure 8 (c) shows a $\mathrm{ZrB}_{2}-15 \mathrm{vol} \% \mathrm{SiC}$ composite fabricated at CNR-ISTEC and oxidized at $1550^{\circ} \mathrm{C}$ for $2 \mathrm{~h}$ at UM. The cross sections shown in Figs. 8(a) and (b) closely resemble the cross section of the convection cell shown in Fig. 8(c). Note the similarity in the morphology of the vertical $\mathrm{ZrO}_{2}$ feature of the specimens oxidized at CNR-ISTEC to the morphology of the $\mathrm{ZrO}_{2}$ "island" of the specimen oxidized at UM (indicated by a arrow in Fig. 8). Also, all three specimens shown in Fig. 8 have thicker $\mathrm{ZrO}_{2}$ layer (enhanced oxidation zone) under the vertical $\mathrm{ZrO}_{2}$ features. The similarity of these images indicate that the convection cells are seen in other boride- $\mathrm{SiC}$ materials such as these $\mathrm{Hf}(\mathrm{Zr}) \mathrm{B}_{2}-\mathrm{SiC}-\mathrm{HfN}$ composites, which have a different relative amount of in $\mathrm{Hf}(\mathrm{Zr}) \mathrm{O}_{2}, \mathrm{SiO}_{2}$, and $\mathrm{B}_{2} \mathrm{O}_{3}$ after oxidation.

Figure 9(a) shows similar features for a $\mathrm{ZrB}_{2}-30 \mathrm{vol} \% \mathrm{SiC}$ composite oxidized for $30 \mathrm{~min}$ at $1400^{\circ} \mathrm{C}$ by Rezaie et al. ${ }^{13}$ at the University of Missouri-Rolla (UMR) previously reported in the literature. Figure 9(b) shows a cross section of a $\mathrm{ZrB}_{2}-15 \mathrm{vol} \%$ $\mathrm{SiC}$ composite (fabricated at CNR-ISTEC) oxidized for $1 \mathrm{~h}$ at $1550^{\circ} \mathrm{C}$ at UM. The cross sections have very similar microstructural features: enhanced oxidation zone (thicker $\mathrm{ZrO}_{2}$ layer) under a vertical $\mathrm{ZrO}_{2}$ feature. This indicates that convection cells were formed on the $\mathrm{ZrB}_{2}-30 \mathrm{vol} \% \mathrm{SiC}$ composite during
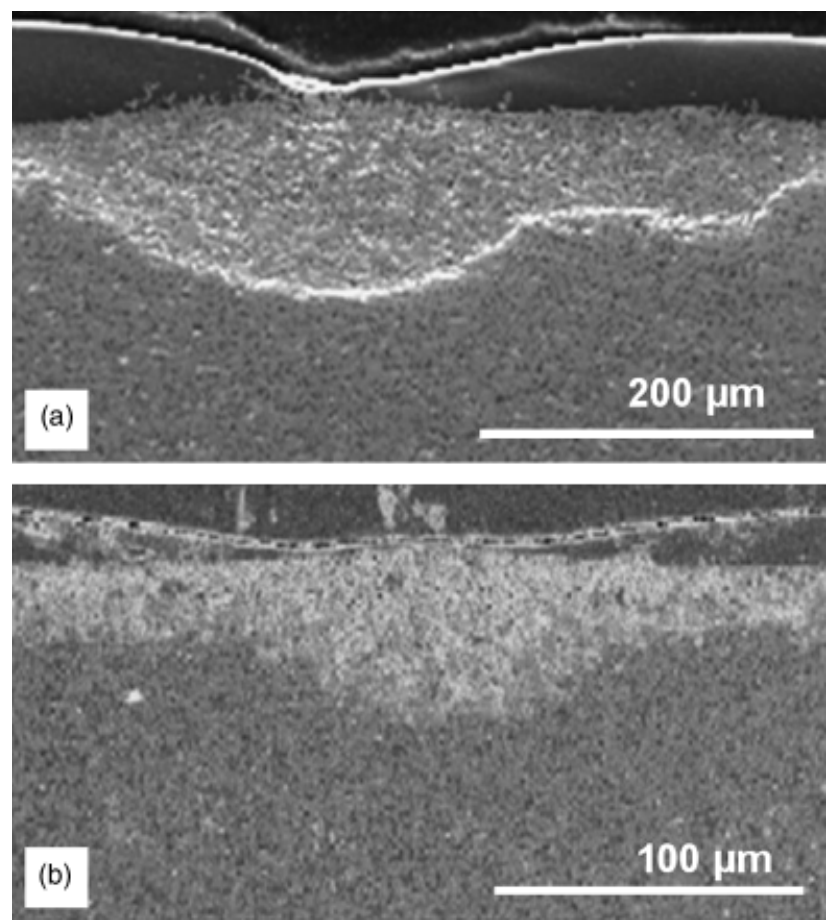

Fig. 9. Cross sections of $\mathrm{ZrB}_{2}-\mathrm{SiC}$ composites. (a) $\mathrm{ZrB}_{2}-15 \% \mathrm{SiC}$ oxidized at $1550^{\circ} \mathrm{C}$ for $1 \mathrm{~h}$ and (b) $\mathrm{ZrB}_{2}-30 \mathrm{vol} \%$ SiC oxidized at $1400^{\circ} \mathrm{C}$ for 30 min by Rezaie et al. ${ }^{13}$ 
oxidation. Figure 10(a) shows a micrograph of the surface of the $\mathrm{ZrB}_{2}-\mathrm{SiC}$ specimen oxidized for $1 \mathrm{~h}$ at $1550^{\circ} \mathrm{C}$ at $\mathrm{UM}$. The image shows how the convection cells are spread over the surface, forming a pattern with small micrometer-sized $\mathrm{ZrO}_{2}$ particles located between the boundaries of the cells. Figure 10(b) shows the flow pattern of the $\mathrm{ZrO}_{2}$ particles in more detail. No micrographs of the surfaces of the specimens oxidized at CNR-ISTEC or UMR were reported; thus comparison of these surfaces to the UM specimens could not be done.

The features shown in previously published micrographs from CNR-ISTEC and UMR are suggested here to be in fact convection cells. These findings indicate that the convection cells do exist for other oxidized boride-SiC materials but have not been brought to attention in the literature or interpreted as of significance for the oxidation behavior of these materials.

\section{Subscale Recession: Enhanced Oxidation Regions}

Now let us direct our attention to the local regions of enhances oxidation shown in Figs. 4(d), 8 and 9. These are the areas with more diboride recession (deeper) and thicker oxide scales (thicker $\mathrm{ZrO}_{2}$ layer) under the convection cell features. Why do these form? Our hypothesis is based on inward diffusion of oxygen. Let us assume that the rate of diboride oxidation is limited by inward oxygen transport as has been reported previously in the UHTC literature. ${ }^{2,13,14}$ Areas of greater recession demand greater inward oxygen diffusion to leave a thicker scale. The driving force is similar; hence, the oxygen diffusivity must be locally higher. Here we can invoke the Stokes-Einstein relation $^{15}$ between diffusivity and viscosity, derived from studies of the Brownian motion of a solid sphere suspended in a fluid, where the particle's diffusivity is inversely proportional to the fluid viscosity, i.e. $D \sim 1 / \eta$, more specifically ${ }^{15-17}$

$$
D=\frac{k_{\mathrm{B}} T}{6 \pi \eta r}
$$

where $D$ is the diffusion coefficient, $k_{\mathrm{B}}$ the Boltzmann constant, $r$ is the radius of the slowest particle moving through the fluid (the hydrodynamic radius), and $T$ the absolute temperature. Another similar equation based on the theory of absolute reaction rates by Eyring ${ }^{18}$ is sometimes preferred for silicate glasses to relate melt viscosities to the diffusion coefficients of oxygen in molten silicates ${ }^{16,18,19}$ :

$$
D=\frac{k_{\mathrm{B}} T}{\lambda \eta}
$$

where $\lambda$ is the mean jump distance of the diffusing particle $\left(\mathrm{O}^{-2}\right)$.

In the $\mathrm{SiO}_{2}$-rich scale, the viscosity at oxidation temperatures of $1500^{\circ} \mathrm{C}$ is on the order of $10^{11}$ Poise $\left(10^{10} \mathrm{~Pa} \cdot \mathrm{s}\right) .^{20}$ With the

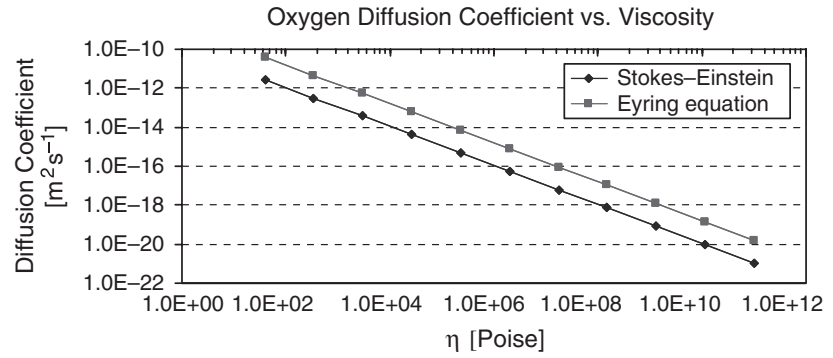

Fig. 11. Diffusion coefficient of oxygen in a $\mathrm{B}_{2} \mathrm{O}_{3}-\mathrm{SiO}_{2}$ melt at $1550^{\circ} \mathrm{C}$ calculated by using the Stokes-Einstein relation (diamonds) and the Eyring equation (squares) versus the shear viscosity (logarithmic scale).

presumed composition of BSZ liquid, ${ }^{10}$ we have estimated based on limited data in the literature that the viscosity will be about $10^{4}$ Poise $\left(10^{3} \mathrm{~Pa} \cdot \mathrm{s}\right)^{8,9,20}$; this is a large viscosity difference, by about factor of $10^{7}$. This implies that in the local regions of the BSZ liquid pipes, the diffusivity for inward diffusion of oxygen must be larger by a similar factor, about $10^{7}$ times faster oxygen transport than in the $\mathrm{SiO}_{2}$ scale remote from the pipe. When the convection cell forms (the deformation erupts) outward flow of material of low viscosity (BSZ liquid) occurs and a localized inward path for oxygen will be created. A synergy between oxygen transport in and liquid transport out occurs. Thus we expect a complex coupling of these phenomena.

Oxygen can diffuse through amorphous $\mathrm{SiO}_{2}$ via two mechanisms: (1) so-called network oxygen ions can diffuse through the $\mathrm{SiO}_{4}$ tetrahedral network and (2) interstitial (nominally molecular) oxygen can diffuse through the free volume of the silicate structure. ${ }^{21}$ For the network oxygen ion diffusion the Eyring can be used to estimate the oxygen diffusion coefficient by using $\lambda$ as the mean jump distance of the diffusing particle $\left(\mathrm{O}^{-2}\right) \cdot{ }^{16,18,19}$ The diffusion coefficient of interstitial oxygen diffusion (molecular) can be estimated by using the Stokes-Einstein relation with $r$ (hydrodynamic radius) substituted by the $\mathrm{O}_{2}$ bond length (1.21 A). ${ }^{22}$ The two mechanisms can operate simultaneously and most likely have different temperature dependencies. Thus oxidation at different temperatures could be governed by either mechanism. ${ }^{21}$ The question of whether oxygen diffuses through $\mathrm{SiO}_{2}$ as a molecule or ionically or perhaps both remains unclear, which has led to a broad range of reported diffusion coefficients. ${ }^{16,17,19,21-28}$

Figure 11 shows the calculated diffusion coefficient of oxygen in a borosilicate melt versus the viscosity, calculated with the Stokes-Einstein relation and the Eyring equation. For the Stokes-Einstein relation the following parameter were used; $T=1550^{\circ} \mathrm{C}$, and $r=1.21 \mathrm{~nm}$ (where the $\mathrm{O}_{2}$ bond length is used for the hydrodynamic radius of $\mathrm{O}_{2}^{22}$ ) and viscosity values are estimated by relationship extrapolated from data by Jabra and colleagues. ${ }^{9,20}$ The same viscosity values were used for the Eyring equation as well as $T=1550^{\circ} \mathrm{C}$, and $\lambda=0.159 \mathrm{~nm}$, which is the $\mathrm{Si}-\mathrm{O}$ distance in $\mathrm{SiO}_{2}$ glass. ${ }^{19}$ The diffusion coefficients
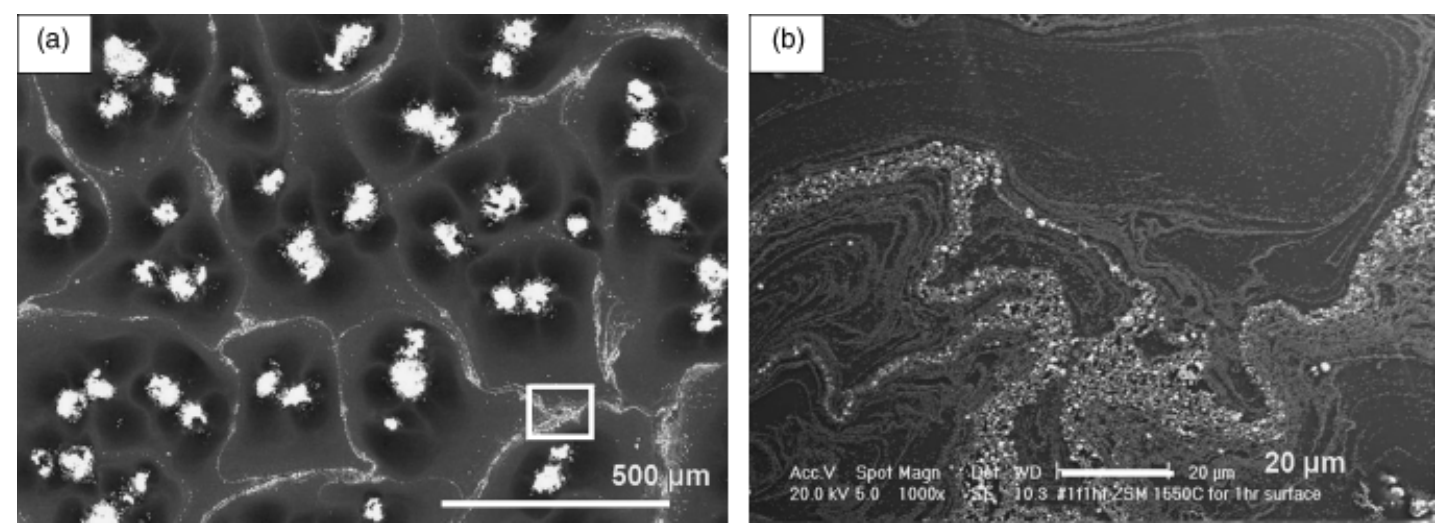

Fig. 10. Backscattered electron images of the surface of a $\mathrm{ZrB}_{2}-\mathrm{SiC}$ composite oxidized at $1550^{\circ} \mathrm{C}$ for $1 \mathrm{~h}$ shown earlier in cross-sectional view in Fig. 10(b); (a) low magnification (b) high magnification of the area inside the white box in (a). 


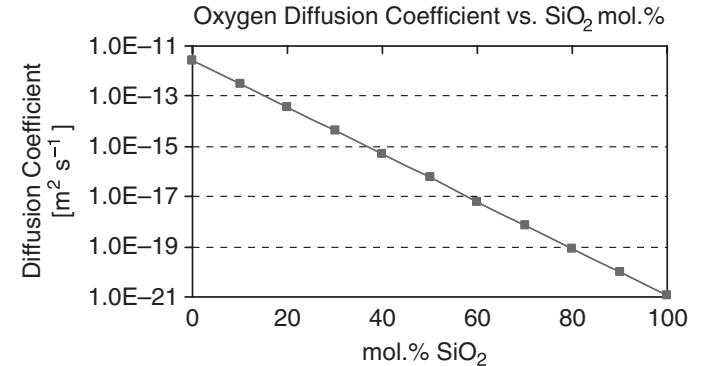

Fig. 12. Diffusion coefficient of oxygen in a $\mathrm{B}_{2} \mathrm{O}_{3}-\mathrm{SiO}_{2}$ melt versus $\mathrm{SiO}_{2} \mathrm{~mol} \%$ calculated using the Stokes-Einstein relation.

calculated by the two equations differ on the order of about one magnitude. The difference is not large compared with the wide range of values reported in the literature; also these values are comparable to measured and calculated values reported previously. $16,17,19,21-29$

Figure 12 shows the diffusion coefficient of oxygen in a borosilicate melt versus $\mathrm{mol} \%$ of $\mathrm{SiO}_{2}$ estimated by using the StokesEinstein relation with $T=1550^{\circ} \mathrm{C}, r=0.121 \mathrm{~nm}$, and viscosity values estimated from data by Jabra and colleagues. ${ }^{9,20}$ Figure 12 shows how the inward oxygen diffusion decreases with an increase in $\mathrm{SiO}_{2} \mathrm{~mol} \%$ in $\mathrm{a}_{2} \mathrm{O}_{3}-\mathrm{SiO}_{2}$ melt. This is indicated by the low diffusion coefficient of oxygen for a pure $\mathrm{SiO}_{2}$ melt $(100 \mathrm{~mol} \%$ $\left.\mathrm{SiO}_{2} ; D=1.1 \times 10^{-21} \mathrm{~m}^{2} / \mathrm{s}\right)$ compared with a $\mathrm{B}_{2} \mathrm{O}_{3}$-rich melt $(79$ $\mathrm{mol}^{\%} \mathrm{~B}_{2} \mathrm{O}_{3}-21 \mathrm{~mol}^{\%} \mathrm{SiO}_{2} ; D=1.7 \times 10^{-14} \mathrm{~m}^{2} / \mathrm{s}$ ), which is $10^{7}$ times larger, as estimated from the large viscosity difference mentioned above. The calculated diffusion coefficients of oxygen in borosilicate melts (Fig. 12) is smaller than the diffusion coefficient for oxygen in $\mathrm{ZrO}_{2}\left(\sim 10^{-10} \mathrm{~m}^{2} / \mathrm{s}\right.$ at $\left.1500^{\circ} \mathrm{C}\right)$ reported by Fox and Clyne ${ }^{28}$ supporting our previous assumption that the borosilicate outer layer is the oxygen diffusion barrier (the rate controlling factor) during oxidation at these temperatures.

The local enhanced oxidation regions under the convection cells makes the oxidation of diboride-SiC composites at these temperatures a nonuniform process at a microscopic scale. Observations of apparently uniform oxidation behavior reported in the literature could result from the fine scale of the local events. Just like an intergranular corrosion may be quite homogenous on the macroscopic scale, it is though localized on a microscopic scale. ${ }^{30}$ Perhaps in the early state of the oxidation uniform oxygen diffusion generates a pool of BSZ liquid. When the volume of the liquid and the pressure (by Pillings-Bedworth ratio) reaches a critical amount, it erupts. While it is erupting, oxygen can diffuse in by the same path; hence, it oxidizes faster under a cell creating the enhanced oxidation zone.

\section{Summary}

Oxide scale features previously published in the literature on $\mathrm{ZrB}_{2}-\mathrm{SiC}$ and $\mathrm{HfB}_{2}-\mathrm{SiC}$ composites are suggested here to be in fact the proposed convection cells reported for the first time by the authors. ${ }^{9}$ These features are of great significance contributing to the formation of complex oxide scales of these materials. The flow of a $\mathrm{B}_{2} \mathrm{O}_{3}$-rich $\mathrm{BSZ}$ liquid to the surface, with the subsequent loss of $\mathrm{B}_{2} \mathrm{O}_{3}$ to evaporation, explains the formation of a glassy $\mathrm{SiO}_{2}$-rich layer on the surface commonly reported in the literature. Also the outward flow of the BSZ liquid creates a localized inward path for oxygen due to lower viscosity that allows faster oxidation under the convection cell. The formation of a convection cell (eruption of the "primary" scale) creates a leak in the $\mathrm{SiO}_{2}$ barrier, but the BSZ liquid eventually replenishes the $\mathrm{SiO}_{2}$ scale, patching the leak creating a positive feedback.

\section{Acknowledgments}

We thank Dr. David Shifler of the Office of Naval Research for supporting the research under contract N00014-02-1-0034 and Drs. Alida Bellosi, Frederick
Monteverde, Gregory Hilmas, and William Farhenholtz for providing samples and valuable discussions.

\section{References}

${ }^{1}$ F. Monteverde and A. Bellosi, "The Resistance to Oxidation of $\mathrm{HfB}_{2}-\mathrm{SiC}$ Composite," J. Eur. Ceram. Soc., 25, 1025-31 (2005).

${ }^{2} \mathrm{~F}$. Monteverde and A. Bellosi, "Oxidation of $\mathrm{ZrB}_{2}$-Based Ceramics in Dry Air," J. Electrochem. Soc., 150 [11] B552-9 (2003).

${ }^{3}$ A. Chamberlain, W. Fahrenholtz, G. Hilmas, and D. Ellerby, "Oxidation of $\mathrm{ZrB}_{2}-\mathrm{SiC}$ Ceramics Under Atmospheric and Reentry Conditions," Refract. Appl. Trans., 1 [2] 1-8 (2005).

${ }^{4}$ S. R. Levine, E. J. Opila, M. C. Halbig, J. D. Kiser, M. Singh, and J. A. Salem, "Evaluation of Ultra-High Temperature Ceramics for Aeropropulsion Use," J. Eur. Ceram. Soc., 22, 2757-67 (2002).

${ }^{5}$ W. G. Fahrenholtz, "Thermodynamic Analysis of $\mathrm{ZrB}_{2}-\mathrm{SiC}$ Oxidation: Formation of a SiC-Depleted Region," J. Am. Ceram. Soc., 90 [1] 143-8 (2007).

${ }^{6}$ M. M. Opeka, I. G. Talmy, and J. A. Zaykoski, “Oxidation-Based Materials Selection for $2000^{\circ} \mathrm{C}+$ Hypersonic Aerosurface: Theoretical Considerations and Historical Experience," J. Mater. Sci., 39 [19] 5887-904 (2004).

${ }^{7}$ A. Bongiorno, C. J. Först, R. K. Kalia, J. Li, J. Marschall, A. Nakano, M. M Opeka, I. G. Talmy, P. Vashishta, and S. Yip, "A Perspective on Modeling Material in Extreme Environments: Oxidation of Ultra-High Temperature Ceramics," Mater. Res. Soc. Bull., 31, 410-8 (2006).

${ }^{8}$ P. C. Setze, A Review of the Physical and Thermodynamic Properties of Boric Oxide. NACA-RM-E57B14. Lewis Flight Propulsion Laboratory, Cleveland, $\mathrm{OH}$, 1957.

${ }^{9}$ S. N. Karlsdottir, J. W. Halloran, and C. E. Henderson, "Convection Patterns in Liquid Oxide Films on Zirconium Diboride-Silicon Carbide Composites Oxidized at High Temperature," J. Am. Ceram. Soc., 90 [9] 2863-7 (2007).

${ }^{10}$ S. N. Karlsdottir, J. W. Halloran, and A. N. Grundy, "Zirconia Transport by Liquid Convection During Oxidation of Zirconium Diboride-Silicon Carbide Composite," J. Am. Ceram. Soc., 91 [1] 272-7 (2008).

${ }^{11}$ S. N. Karlsdottir, J. W. Halloran, F. Monteverde, and A. Bellosi, "Oxidation of ZrB2-SiC: Comparison of Furnace Heated Coupons and Self-Heated Ribbon Specimens"; in Proceedings of the 31st International Conference on Ceramics and Composites, Daytona Beach FL, January 21-26, 2007. Mechanical Properties and Performance of Engineering Ceramics and Composites III, Edited by E. LaraCurzio. Ceram. Trans., 28 [2] 327-336 (2007).

${ }^{12}$ F. Monteverde, "The Thermal Stability in Air of Hot Pressed Diboride Matrix Composites for Uses at Ultra-High Temperatures," Corros. Sci., 47, 2020-33 (2005).

${ }^{13}$ A. Rezaie, W. G. Fahrenholtz, and G. E. Hilmas, "Evolution of Structure During the Oxidation of Zirconium Diboride-Silicon Carbide in Air up to $1500^{\circ}$ C," J. Eur. Ceram. Soc., 27 [6] 2495-501 (2007).

${ }^{14} \mathrm{~F}$. Monteverde, "Beneficial Effects of an Ultra-Fine $\alpha$-SiC Incorporation on the Sinterability and Mechanical Properties of $\mathrm{ZrB}_{2}$," Appl. Phys. A, 82, 329-37 (2006).

${ }^{15} \mathrm{~A}$. Einstein, Investigations on the Theory of the Brownian Movement, reprinted by Dover Publications, New York, 1926.

${ }^{16}$ Y. Liang, F. M. Richter, A. M. Davis, and E. B. Watson, "Diffusion in Silicate Melts: I. Self Diffusion in $\mathrm{CaO}-\mathrm{Al}_{2} \mathrm{O}_{3}-\mathrm{SiO}_{2}$ at $1500^{\circ} \mathrm{C}$ and $1 \mathrm{GPa}$," Geochim. Cosmochim. Acta, 60 [22] 4353-67 (1996).

${ }^{17}$ E. M. Tanguep Njiokep and H. Mehrer, "Diffusion of ${ }^{22} \mathrm{Na}$ and ${ }^{45} \mathrm{Ca}$ in Ionic Conduction in Two Standard Soda-Lime Glasses," Solid State Ionics, 177, 2839 44 (2006).

${ }^{18} \mathrm{H}$. Eyring, "Viscosity, Plasticity, and Diffusion as Examples of Absolute Reaction Rates," J. Chem. Phys., 4 [4] 283-91 (1936).

${ }^{19}$ M. L. Ferreira Nascimento and E. D. Zanotto, "Mechanisms and Dynamics of Crystal Growth, Viscous Flow, and Self-Diffusion in Silica Glass," Phys. Rev. $B, 73,024209$ (2006)

${ }^{20}$ R. Jabra, J. Phalippau, and J. Zarzicki, "Synthesis of Binary Glass-Forming Oxide Glasses by Hot-Pressing," J. Non-Cryst. Solids, 42, 489-98 (1980).

${ }^{21}$ C. E. Ramberg and W. L. Worrell, "Oxygen Transport in Silica at High Temperatures: Implications of Oxidation Kinetics," J. Am. Ceram. Soc., 84 [11] $2607-$ 16 (2001).

${ }^{22}$ J. Read, K. Mutolo, M. Ervin, W. Behl, J. Wolfenstine, A. Driedger, and D. Foster, "Oxygen Transport Properties of Organic Electrolytes and Performance of Lithium/Oxygen Battery,” J. Electrochem. Soc., 150 [10] A1351-6 (2003).

${ }^{23}$ R. H. Doremus, "Transport of Oxygen in Silicate Glasses," J. Non-Cryst. Solids, 349, 242-7 (2004).

${ }^{24}$ Y. Zhang, E. M. Stolper, and G. J. Wasserburg, "Diffusion of a Multi-Species Component and its Role in Oxygen and Water Transport in Silicates," Earth Planet Sci. Lett., 103, 228-40 (1991).

${ }^{25}$ E. L. Williams, "Diffusion of Oxygen in Fused Silica," J. Am. Ceram. Soc. 48 [4] 190-4 (1965).

${ }^{26}$ D. Tinker, C. E. Lesher, and I. D. Hutcheon, "Self-Diffusion of Si and O in Diopside Anorthite Melt at High Pressure," Geochim. Cosmochim. Acta, 67 [1] 133-42 (2003).

${ }^{27}$ F. J. Norton, "Permeation of Gaseous Oxygen Through Vitreous Silica," $\mathrm{Na}$ ture, 191, 701 (1961)

${ }^{28}$ A. C. Fox and T. W. Clyne, "Oxygen Transport by Gas Permeation Through the Zirconia layer in Plasma Sprayed Thermal Barrier Coatings," Surf. Coat. Technol., 184, 311-21 (2004).

${ }^{29}$ J. D. Cawley, J. W. Halloran, and A. R. Cooper, "Oxygen-18 Tracer Study of the Passive Thermal Oxidation of Silicon," Oxid. Met., 28 [1-2] 1-15 (1987).

${ }^{30}$ R. Telle, L. S. Sigl, and K. Takagi, "Transition Metal Boride Ceramics"; pp. 140-54 in Handbook of Ceramic Hard Materials, Vol. 1, Edited by R. Reidel Wiley-VCH, Weinheim, Germany, 2000. 